\title{
Importance of Serum VEGF and Basic FGF Levels in Determining Response to Treatment And Survival in Patients with Metastatic Colorectal Cancer
}

\author{
Muge KESKIN ${ }^{1}$, Zeki USTUNER ${ }^{2}$, Murat DINCER ${ }^{3}$, Durmus ETIZ ${ }^{4}$, H. Eray CELIK ${ }^{5}$, Zafer GULBAS ${ }^{6}$ \\ ${ }^{1}$ Eskisehir Osmangazi University Faculty of Medicine, Department of Internal Medicine, Eskisehir \\ ${ }^{2}$ Umit Hospital, Department of Medical Oncology, Eskisehir \\ ${ }^{3}$ Eskisehir Osmangazi University Faculty of Medicine, Department of Medical Oncology, Eskisehir \\ ${ }^{4}$ Eskisehir Osmangazi University Faculty of Medicine, Department of Radiation Oncology, Eskisehir \\ ${ }^{5}$ Osmangazi University Faculty of Letters and Science Department of Biostatistics, Eskisehir \\ ${ }^{6}$ Department of Hematology, Anatholian Health Center, Gebze, TURKEY
}

\begin{abstract}
Colorectal cancer has an important place in worldwide death from cancer causes. Angiogenesis, in which angiogenic factors such as VEGF and basic FGF have a key role, is an important factor in patient survival with respect to progression and metastatic spreading in colorectal cancer. In this study, we aimed to determine whether serum VEGF and bFGF pre- and post-treatment serum levels are decisive in evaluating response to treatment and progression in metastatic colorectal cancer (mCRC) patients treated with FOLFIRI-bevacizumab. In $33 \mathrm{mCRC}$ patients serum VEGF and bFGF levels were monitored the beginning of treatment and until progression during FOLFIRIbevacizumab. In our study serum VEGF and bFGF levels were significantly higher than the healthy controls ( $p<0.001)$. We found that the patients with pre-treatment high serum bFGF levels have significantly short Progression free survival. In patients with pre-treatment low serum VEGF value (<147.79 pg/ml) had significantly longer overall survival (27.93 vs 23.27 months p:0.026) in metastatic rectum cancer. In multivariate analysis were found to be prognostic factors VEGF levels, response to treatment and side of the tumor for PFS and VEGF levels, response to treatment and whether to be operated of tumor for overall survival. Conclusions: Serum VEGF level was detected to be one of the factors that determine PFS and overall survival in mCRC. Pre-treatment serum bFGF levels were determined PFS and monitorization of serum bFGF during treatment was found to be related to response to treatment. Although there was no statistical significance, in $\mathrm{mCRC}$ patients, whose pre-treatment serum VEGF were high, PFS was longer with bevacizumab treatment. The importance of pretreatment high serum VEGF level to select for treatment of bevacizumab will be planned in metastatic CRC requires to be confirmed in comprehensive, prospective studies.
\end{abstract}

Keywords: Metastatic colorectal cancer, VEGF, bFGF, Bevacizumab

\section{ÖZET}

\section{Metastatik Kolon Kanserli Hastalarda Tedaviye Yanıtı ve Sağkalımı Değerlendirmede Serum VEGF ve Başlangıç FGF Se-} viyelerinin Önemi

Kolorektalkanserindünyadakikansernedenliölümleriçindeönemlibiryerivardır. VEGF,bFGFgibianjiojenikfaktörlerinanahtarroloynadığıanjiojenez, tümor progresyonu, metastatik yayılım ve hasta genel sağ kalımında önemli bir faktördür. Bu çalışmada; FOLFIRI-bevacizumab ile tedavi edilen metastatic kolorektal kanserli (mkrk) hastalarda; VEGF, bFGF 'in tedavi öncesi ve sonrası düzeylerinin tedaviye yanıtı, ve hastalık progresyonunda ki yerini değerlendirmeyi amaçladık. Otuzüç mkrk'li olguda serum VEGF, bFGF düzeyi tedavi başlangıcı ve tedavi sürecinde monitörize edildi. 
Çalışmamızda hasta grubunda serum VEGF ve bFGF düzeyi sağlıkı kontrol grubuna oranla yüksek saptandı $(p<0.001)$.Başlangıç bFGF düzeyi yüksek olan olgularda hastalıksız sağkalım anlamlı olarak kısa saptandı. Metastatik rektum kanserinde; başlangıç VEGF düzeyi düşük olan hastalarda $(<147.79$ pg/ml) genel sağ kalım anlamlı olarak uzun bulundu (27.93vs 23.27 ay) .Multivariet analizinde; tüm sağ kalım için prognostic faktörler olarak; VEGF düzeyleri, tedavi yanıt, PFS ve VEGF için tümörün yeri, ve tümörün ameliyat edilip edilmediği olarak bulundu. MKRK'li olgularada tedavi öncesi serum VEGF düzeyi HSK ve GSK için önemli bir faktör olarak değerlendirildi. Tedavi öncesi serum bFGF düzeyleri belirlendi. Hastalıksız sağkalım ve tedavi sırasında serum bFGF düzeylerinin belirlenmesi tedaviye yanıt ile ilişkili bulundu.. Tedavi öncesi VEGF düzeyleri yüksek olan mkrk'lı hastalarda istatistiksel anlamlılık olmamasına rağmen bevacizumab tedavisiyle hastalıksız sağ kalım daha uzundu. MKRK'da Bevacizumab tedavisinin seçiminde ve planlamasında tedavi öncesi yüksek VEGF düzeyinin önemi, kapsamlı, prospektif çalışmalarla da onaylanmalıdır.

Anahtar Kelimeler: Metastatik kolorektal kanser, VEGF, bFGF, Bevacizumab

\section{INTRODUCTION}

Colorectal cancer (CRC) is the fourth most common cancer in men and women (1). CRC represents a major public health issue due to its high prevalence and mortality rate. ${ }^{2,3}$ Angiogenesis is essential for cancer growth and metastasis. VEGF is a key modulator of angiogenesis, and its over expression is correlated with advanced disease and poor prognosis. ${ }^{4}$ Bevacizumab, a recombinant humanized anti-VEGF $\mathrm{mAb}$, is the most advanced anti-angiogenic agent clinically. ${ }^{5}$ The integration of bevacizumab in the management of CRC has provided major improvements for patients with metastatic CRC disease. ${ }^{6}$

Investigations are currently underway to determine genetic profiles or other patient characteristics that may be of use in identifying patients who will benefit from targeted agents and how best to combine those agents with the standard cytotoxic regimens .${ }^{1}$ It has been reported that the establishment of VEGF and bFGF levels in circulation may provide information on the tumor vascularity and the response to antiangiogenic therapy. ${ }^{7}$ We aimed to determine whether the surveillance of serum VEGF and bFGF levels can be beneficial in terms of evaluating the therapy response and survival of $\mathrm{mCRC}$ patients treated with FOLFIRI-bevacizumab.

\section{PATIENTS AND METHODS}

Between September 2006 and May 2008, 33 patients histologically diagnosed with metastatic colon or rectum cancer to receive first-line treatment were established to be eligible for the study. The median age (range) was 61 (38-75) years. Healthy control group was 59 (41-71)years. After obtaining informed consent the patients were involved in the study and the local Ethical, Committee approved the study. Blood samples for serum levels VEGF and bFGF were collected at baseline and on Day 1 of chemotherapy cycles 4,8 , and 12 at the Medical Oncology Department of Eskisehir Osmangazi University. Patients were evaluated according to their radiological assessments, and tests that involve hematological and biochemical parameters as well as tumor markers that were performed before the initiation of the therapy. Response evaluation was carried out according to RECIST V1.1 response criteria at every 4th cycle of the chemotherapy. Hematological and biochemical parameters were repeated before every cycle of the chemotherapy.

All patients received bevacizumab $5 \mathrm{mg} / \mathrm{kg}$ IV (day 1) combined with irinotecan $180 \mathrm{mg} / \mathrm{m}^{2} \mathrm{IV}$ (day 1), leucovorin (LV) $200 \mathrm{mg} / \mathrm{m}^{2} \mathrm{IV}$ (day 1) and 5 -fluorouracil (FU) $\left(400 \mathrm{mg} / \mathrm{m}^{2}\right.$ IV bolus and then $2600 \mathrm{mg} / \mathrm{m}^{2}$ continuous infusion for 46 hours) IV once every 2 weeks for 12 cycles. Eligible patients were those completing the whole course without the occurrence of grade 3 or 4 toxicity or tumor progression.

The control group consisted of 21 healthy volunteers, whose serum samples were collected in sterile test tubes, centrifuged at $3000 \mathrm{~g}$ for $10 \mathrm{~min}$, and then stored at $-80^{\circ} \mathrm{C}$. 


\begin{tabular}{|llll|}
\hline Table 1. Patient characteristics & & Number of patients & Percentage \\
\hline \multirow{2}{*}{ Sex } & Male & 23 & 69.7 \\
& Female & 10 & 30.3 \\
Operation Status & Operated & 28 & 84.8 \\
& Not Operated & 5 & 15.2 \\
Chemotherapy Line & First Line & 22 & 66.7 \\
& Second Line & 11 & 33.3 \\
Metastatic Organs (No.) & 1 & 24 & 72.7 \\
& 2 & 8 & 24.2 \\
Location of Metastasis & 3 & 1 & 3.0 \\
& Liver & 13 & 39.4 \\
Tumor Location & Other Liver & 20 & 60.6 \\
& Colon & 18 & 54.5 \\
& Rectum & 15 & 45.5 \\
\hline
\end{tabular}

Serum VEGF concentrations were determined by a quantitative sandwich enzyme immunoassay technique (Invitrogen Immunoassay Kit), described by Salven. ${ }^{8}$ Serum VEGF concentrations between 40 and $600 \mathrm{pg} / \mathrm{ml}$ were reported by the manufacturer. The serum VEGF level of the control group was established to be $85.26 \mathrm{pg} / \mathrm{ml}$ (median $93.60 \mathrm{pg} /$ $\mathrm{ml}$ ). The upper limit (mean control +1 standart deviation [SD]) was calculated to be $147.79 \mathrm{pg} / \mathrm{ml}$.

Serum bFGF concentrations were determined by a quantitative sandwich enzyme immunoassay technique (Invitrogen Immunoassay Kit). The serum bFGF level of the control group was $32.85 \mathrm{pg} / \mathrm{ml}$ (median $33.5 \mathrm{pg} / \mathrm{ml}$ ). The upper limit (mean control + 1 SD) was calculated to be $37.74 \mathrm{pg} / \mathrm{ml}$.

\section{Statistical Analysis}

Statistical analyzes were carried out by using the SPSS 12.0 for Windows software. Overall survival was calculated by using Kaplan-Meier method, and log-rank test was used for the differences between the survival curves. The Mann-Whitney U and Chi-square tests were used to compare the values in different groups for continuous variables and for categorical variables respectively. Prognostic factors were tested by Cox regression model. We utilized Pearson's correlation coefficient to evalu- ate the correlations between VEGF and bFGF, and the clinical parameters. The pre and post-treatment values were compared by using the paired samples $\mathrm{t}$ test. In all statistical analyzes $\mathrm{p}$ value, less than 0.05 was considered significant.

\section{RESULTS}

A total of 33 metastatic colorectal cancer patients receiving bevacizumab combined with chemotherapy were enrolled into the study. The median age of the patients was 61 years (38-75). Out of the 33 patients, 23 were females $(69.7 \%)$. Characteristics of patients are summarized in Table 1 . The patients received 12 courses of FOLFIRI-bevacizumab therapy or until the disease progressed.

The response rates included partial response being $33.3 \%$, stable disease being $36.3 \%$, and progressive disease being $30.3 \%$. The patients with progressive disease continued to receive treatment of chemotherapy (CT) schemas which was not delivered previously.

The mean of VEGF parameters of the control group was $85.26 \pm 62.53 \mathrm{pg} / \mathrm{ml}$ while the median was $93.60 \mathrm{pg} / \mathrm{ml}$, and the upper limit value was calculated $147.79 \mathrm{pg} / \mathrm{ml}$ with addition of mean + standard deviation. The mean of bFGF parameters of the control group was $32.85 \pm 4.89 \mathrm{pg} / \mathrm{ml}$ while 


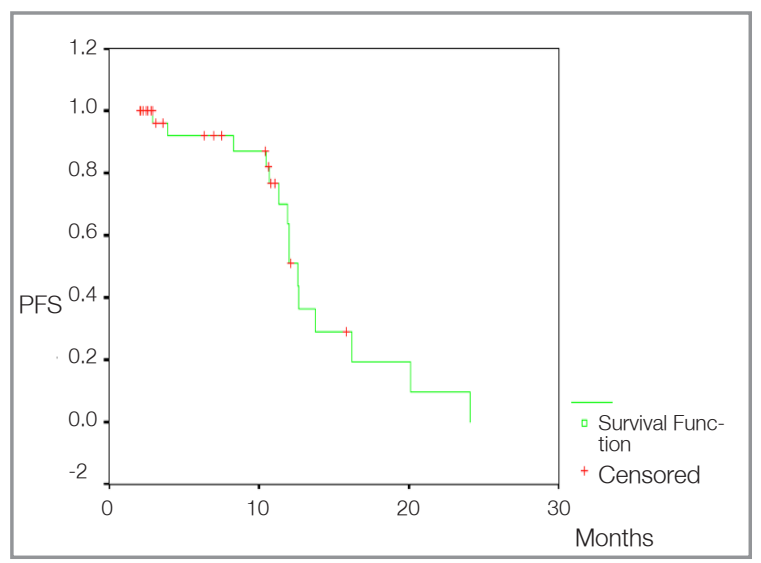

Figure 1. Progression free survival(PFS) in the patients

the median was $33.5 \mathrm{pg} / \mathrm{ml}$, and the upper limit value was calculated to $37.74 \mathrm{pg} / \mathrm{ml}$ with addition of mean + standard deviation . The mean was 245.39 $\mathrm{pg} / \mathrm{ml}$ and the median was $171 \mathrm{pg} / \mathrm{ml}$ for VEGF whereas the mean was $43.70 \mathrm{pg} / \mathrm{ml}$ and the median was $43.90 \mathrm{pg} / \mathrm{ml}$ for bFGF. The serum levels of VEGF and bFGF were significantly higher in the patient group than those of the control group $(\mathrm{p}<$ 0.001 vs. $\mathrm{p}<0.001$ ). Out of the 33 patients, 20 died $(60.6 \%)$ during followup period. Mean overall survival of our patients were 13.53 months and mean progression-free survival of our patients was 23.97 months. (Figure 1 and Figure 2)

Features of the patients were evaluated by the univariate analysis for progression-free survival (PFS), and bFGF ( $\mathrm{p}=0.026$ ) was found to be a significant factor on PFS. As to overall survival. VEGF parameters of the patients were compared

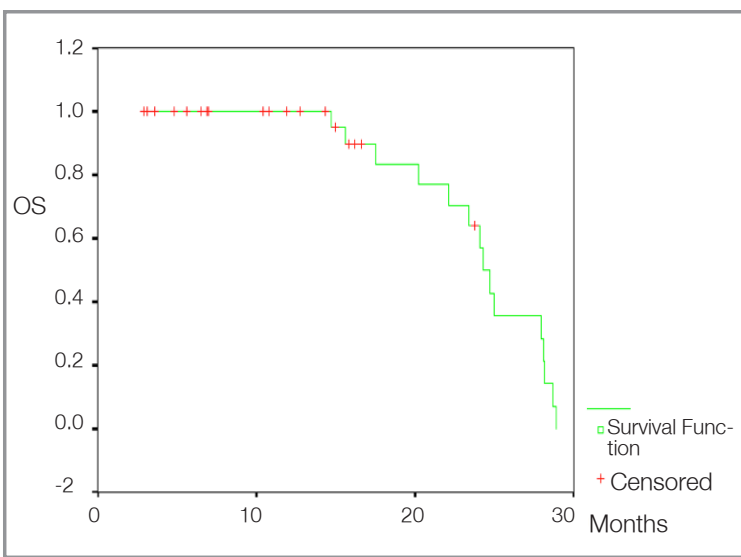

Figure 2. Overall survival (OS) in the patients

according to their condition under chemotherapy (partial response, stable disease or progressive disease). VEGF parameters of 11 patients with partial response under chemotherapy were compared to VEGF parameters prior to chemotherapy, and statistically significant differences were found $(\mathrm{p}<$ $0.01)$. In a partial response case, VEGF parameters of 12 patients with a stable response demonstrated significant differences in comparison to initial parameters $(\mathrm{p}<0.05)$. There were statistically significant differences between the VEGF parameters and initial VEGF parameters of ten patients progressing under chemotherapy $(\mathrm{p}<0.05)$. There was a statistically strong positive correlation between the initial and final (12th month) VEGF parameters of patients with partial response $(r=0.820$; $p<$ 0.01 ). No correlation was found between the initial and final VEGF parameters of the patients with a stable response and progressive course. There were

\begin{tabular}{|c|c|c|c|c|c|c|c|c|c|c|c|}
\hline $\begin{array}{l}\text { Chemotherapy } \\
\text { Response }\end{array}$ & n & $\begin{array}{l}\text { VEGF-01 } \\
\text { Mean } \pm \text { SE }\end{array}$ & $\begin{array}{l}\text { VEGF-12 } \\
\text { Mean } \pm \text { SE }\end{array}$ & p & $r$ & p & $\begin{array}{l}\text { bFGF- } 0^{3} \\
\text { Mean } \pm \text { SE }\end{array}$ & $\begin{array}{l}\text { bFGF-14 } \\
\text { Mean } \pm \text { SE }\end{array}$ & p & $\mathbf{r}$ & $\mathbf{P}$ \\
\hline $\begin{array}{l}\text { Partial } \\
\text { Response }\end{array}$ & 11 & $351.43 \pm 74.32$ & $42.59 \pm 4.35$ & 0.001 & 0.820 & 0.002 & $43.34 \pm 2.50$ & $41.93 \pm 2.91$ & 0.531 & 0.687 & 0.020 \\
\hline $\begin{array}{l}\text { Stable } \\
\text { Disease }\end{array}$ & 12 & $180.85 \pm 42.22$ & $56.68 \pm 6.88$ & 0.011 & 0.231 & 0.471 & $45.02 \pm 2.32$ & $45.13 \pm 2.22$ & 0.961 & 0.478 & 0.166 \\
\hline $\begin{array}{l}\text { Progressive } \\
\text { Disease }\end{array}$ & 10 & $206.19 \pm 65.76$ & $35.80 \pm 2.75$ & 0.032 & -0.55 & 0.093 & $42.51 \pm 0.96$ & $44.02 \pm 3.15$ & 0.553 & 0.629 & 0.052 \\
\hline
\end{tabular}


no statistically significant differences between the initial and final bFGF parameters for the groups defined by clinical follow-up outcomes of the patients. There was a statistically positive correlation between the initial and final bFGF parameters of the patients with partial response $(\mathrm{r}=0.687 ; \mathrm{p}<$ $0.05)$. No correlation was found between the initial and final bFGF parameters of the patients with a stable response and progressive course. Table 2 presents the comparison results.

Serum VEGF level was not found a significant factor for the patients with rectum and colon cancer in progression free survival whereas sVEGF level was a significant factor for the patients with rectum cancer to determine overall survival.

The factors affecting patients' survival was investigated by multivariate analysis. Sex, tumor localization, chemotherapy stage, metastasis, condition under chemotherapy, operation status, serum VEGF, and bFGF levels were evaluated to be the factors affecting PFS and overall survival in the multivariate analysis. The prognostic factors determining PFS were VEGF $(\mathrm{p}=0.005)$ and tumor localization $(p=0.014)$. The factors affecting the overall survival were the surgical status $(p=0.027)$ and $\operatorname{sVEGF}(\mathrm{p}=0.023)$ in the multivariate analysis.

In addition according to our results; according to the values of under and below values (147.9) of rectal and colon VEGF, there is no difference in progression free survivals $(\mathrm{p}=0.066$ and $\mathrm{p}=0.789$ respectively). According to the values of under and below values (147.9) of rectal and colon VEGF, there is no difference in overall survivals in colon VEGF values $(p=0.016)$ and no difference was found in colon VEGF values $(p=0.709)$. Tumor localization is an important risk factor for progression free- survival and its effect is 21.73 times greater on progression free- survival (Odd's Ratio=21.73). VEGF is also an important risk factor for progression free- survival and its effect is 15.15 times greater on progression free- survival $($ Odd's Ratio= 15.15) $(\mathrm{OR}=21.73, \mathrm{p}=0.014 ; \mathrm{OR}=$ $15.15, \mathrm{p}=0.005)$. Operation status is an important risk factor for overall survival, and its effect is 6.93 as an Odd's Ratio. VEGF is also an important risk factor for overall survival, and its effect is 5.40 as an Odd's Ratio.
The adverse effects detected during BevacizumabFOLFIRI therapy in our study are; hypertension in 10 patients $(30.3 \%)$, bleeding diathesis (hematochezia, hemoptysis, epistaxis) in 6 patients $(18.2 \%)$, proteinuria in 4 patients $(12.1 \%)$, grade III neutropenia in 3 patients $(9.09 \%)$, grade III diarrhea in 3 patients $(9.09 \%)$, grade II-III urticaria in 1 patient $(3.0 \%)$, grade III thrombocytopenia in 1 patient $(3.0 \%)$, hyperthyroidism in 1 patient (3.0\%). During the treatment one patient had pulmonary embolism, one patient had inferior vena caval thrombosis, and one patient had deep vein thrombosis. No intestinal perforation or mortality occurred in relation with the chemotherapy.

\section{DISCUSSION}

Colorectal carcinomas are globally one of the primary causes of mortality of cancer. Approximately $50 \%$ of the patients have relapse despite undergoing a curative surgery and die of metastatic disease. ${ }^{9}$ We investigated the prognostic significance of VEGF and bFGF serum levels, which are important factors of angiogenesis, in colorectal cancer; their value to determine the response to treatment; and whether they were useful to identify the suitable group of patients for bevacizumab therapy in 33 patients diagnosed with metastatic colorectal cancer presented at our clinic.

In 1971, Judah Folkman first proposed that tumor angiogenesis could serve as a potential target for anticancer therapy..$^{10}$ In their study Nakayama et al. ${ }^{11}$ found that the elevated plasma VEGF levels indicated recurrence and poor prognosis. Bevacizumab, the first FDA, approved the angiogenesis inhibitor humanized monoclonal Ig G antibody, inhibits VEGF. ${ }^{12}$ The addition of bevacizumab to fluoropyrimidine-based chemotherapy, with or without irinotecan or oxaliplatin, in both the firstand second-line treatment of metastatic colorectal cancer, significantly increased median progression-free survival (PFS) and overall survival in select randomized phase III studies. ${ }^{13}$ Out of the 33 patients in our study, 28 (84.4\%) had undergone a surgery; 18 (54.5\%) had tumor colon and 15 $(45.5 \%)$ had rectum localized. The patients in our study had FOLFIRI/ bevacizumab, and the median 
PFS was 12.6 months, whereas the median overall survival was 24.3 months.

Hurwitz et al., conducted a study of 813 patients with $\mathrm{mCRC}$ and reported that the median survival increased from 15.6 months to 20.3 months ( $\mathrm{p}<$ 0.001 ) with addition of bevacizumab to irinotecan, bolus 5-fluorouracil, and leucovorin (IFL); PFS increased from 6.2 months to 10.6 months; response rate raised from $34.8 \%$ to $44.8 \%$, and the median duration of response increased from 7.1 months to 10.4 months in the first-line treatment. ${ }^{14}$ Later, Hurwitz et al. conducted a Phase III study of 923 patients and compared 5-fluorouracil (5-FU)/ leucovorin (LV)/ bevacizumab or IFL/ bevacizumab to IFL/placebo in the first-line treatment. Although the overall survival was increased by 18.3 months in the 5-FU/LV /bevacizumab group and 15.1 months in the IFL/placebo group, this was not statistically significant. ${ }^{15}$ In a study by Kabbinavar et al., 241 patients received 5-FU/LV or IFL, and 249 patients received 5-FU/LV/ bevacizumab. The overall survival was respectively 17.9 months, and 14.6 months whereas PFS was 8.8 months and 5.6 months in the 5-FU/LV/ bevacizumab group and the control group. ${ }^{6}$ In the second-line setting bevacizumab in combination with oxaliplatin, fluorouracil, and leucovorin (FOLFOX4) versus FOLFOX-4 for previously treated with mCRC patients was evaluated in ECOG 3200 a phase III randomized study. The bevacizumab arm was found to be associated with a superior response rate $(21.8 \%$ versus 9.2\%), median PFS (7.2 versus 4.8 months), and median OS (12.9 versus 10.8 months). ${ }^{16}$

Broll et al. ${ }^{17}$ indicated a significant correlation between the tumor volume and VEGF serum concentration in their study. They found that increased tumor mass was associated with high serum VEGF levels. Dirix et al. measured VEGF and bFGF in the sera of cancer patients and reported a strong correlation between the serum levels and tumor progression of both of the angiogenic factors. ${ }^{18} \mathrm{Al}-$ though Landriscina et al. found in their study that VEGF level in serum and tumor was correlated with the stage of the disease, the same correlation was not identified in bFGF. ${ }^{19}$ In our study, bFGF significantly decreased in the patients with partial response during serum bFGF follow-up $(p=0.02)$ and increased in patients with a progressive course $(\mathrm{p}=0.052)$.

SerumVEGF was significantly higher in our patient group (median $171 \mathrm{pg} / \mathrm{ml}$ and the mean $245.39 \mathrm{pg}$ / $\mathrm{ml}$ ) than the control group. We compared the initial parameters with final parameters of VEGF by the responses under chemotherapy (partial response, stable response, progressive response) and found a significant decrease in the parameters. A strong positive correlation was found between the initial and final parameters of VEGF only in the patients with partial response.

In the individual analyses conducted for colon and rectum cancer, the patients with rectum cancer who had normal serum levels of VEGF in the beginning of the treatment had significantly longer overall survival than those with higher VEGF (27.93 months vs. 23.37 months) $(\mathrm{p}=0.026)$. The patients with colon cancer, who had normal serum VEGF levels prior to the treatment, lived longer, but this was statistically insignificant. Unlike those with colon cancer, the initial sVEGF level was a significant indicator for overall survival of the patients with rectum cancer in our patients. Furthermore, the patients with partial response initially had a higher sVEGF level, and the PFS was increased by antiVEGF treatment.

It will be more accurate to define carcinogenesis according to molecular characteristics of the tumor and host rather than the stage of the disease. The treatment should be planned not only by tumor localization but also by the molecular biology of the tumor and individual. ${ }^{20}$ When biomarkers are widely and clinically used, they will be helpful with noninvasive treatment planning. ${ }^{21}$ With antiVEGF treatment, the PFS was higher in our patients who initially had high serum VEGF levels. However, this was statistically significant with shorter survival in rectum cancer. In the beginning of this treatment, the overall survival of those with high sVEGF was short but the PFS was longer, which suggests that a greater response to bevacizumab therapy in those with high sVEGF levels could be achieved.

The adverse effects that might occur with the addition of bevacizumab to chemotherapy were 
reported to be GI perforation, complications of hemorrhage, arterial thromboembolism, hypertension, proteinuria, and epistaxis. ${ }^{22}$ We fortnightly administered $5 \mathrm{mg} / \mathrm{kg}$ dose of bevacizumab to the patients. The FOLFIRI /bevacizumab combination regimen was well tolerated by the patients. None of our patients died due to the treatment.

In conclusion, serum VEGF is indicative for PFS and overall survival in patients with $\mathrm{mCRC}$. Based on limited numeral parameters, we also found in our study that serum bFGF levels might be useful to determine the response to the treatment during the course of treatment. The response rate of the patients who initially had higher serum VEGF levels to the antiangiogenic therapy found to be high. This finding suggests that the determination of initial sVEGF levels may be useful to select the patients with mCRC to receive bevacizumab therapy; however this should be supported by further prospective studies.

\section{REFERENCES}

1. Köhne C, Lenz H. Chemotherapy with targeted agents for the treatment of metastatic colorectal cancer. Oncologist 14: 478-488, 2009.

2. Kwon HC, Oh SY, Lee S, et al. Bevacizumab plus infusional 5- fluorouracil, leucovorin and irinotecan for advanced colorectal cancer that progressed after oxaliplatin and irinotecan chemotherapy: A pilot study. World J Gastroenterology 13: 6231-6235, 2007.

3. Jubb AM, Hurwitz HI, Bai W, et al. Impact of vascular endothelial growth factor-A expression, thrombospondin-2 expression, and microvessel density on the treatment effect of bevacizumab in metastatic colorectal cancer. J Clin Oncol 10: 213-216, 2006

4. Hyodo I, Doi T, Endo H, et al. Clinical significance of plasma vasculer endothelial growth factor in gastrointestinal cancer. Eur J Cancer 34: 2041-2045, 1998.

5. Arriaga $\mathrm{Y}$, Becerra CR. Adverse effects of bevacizumab and their management in solid tumors. Support Cancer Ther 3: 247-250, 2006.

6. Kabbinavar FF, Hambleton J, Mass RD, et al. Combined Analysis of Efficacy: The addition of Bevacizumab to Fluorouraci//Leucovorin Improves Survival for Patient With Metastatic Colorectal Cancer. J Clin Oncol 23: 3706-3712, 2005.
7. Davies MM, Jonas SK, Kaur S, Allen-Mersh TG. Plasma vascular endothelial but not fibroblast growth factor levels correlate with colorectal liver metastasis vascularity and volume. Br J Cancer 82: 1004-1008, 2000.

8. Libutti SK, Saltz LB, Tepper JE. Colon cancer. Devita Jr VT, Laurence TS, Rosenberg SA, editors. Cancer Principles and Practice of Oncology. 8th Ed. Philadelphia, Lippincott Williams and Wilkins, 2008: 1232-1282.

9. Prat A, Casado E, Cortés J. New approaches in angiogenic targeting for colorectal cancer. World J Gastroenterol 13 : 5857-5866, 2007.

10. Rmali K.A, Puntis M.C.A, Jiang W.G. Tumour associated angiogenesis in human colorectal cancer. Colorectal Dis 9: 3-14, 2007.

11. Nakayama $Y$, Sako T, Shibao K, et al. Prognostic value of plasma vascular endothelial growth factor in patients with colorectal cancer. Anticancer Res 22: 2437-2442, 2002.

12. Shih $\mathrm{T}$, Lindley $\mathrm{C}$. Bevacizumab: An anjiogenesis inhibitor for the treatment of solid malignancies. Clin Ther 28: 1779-802, 2006.

13. Puthillath A, Patel A, Fakih MG. Targeted therapies in the management of colorectal carcinoma: role of bevacizumab. Onco Targets Ther 2: 1-15, 2009.

14. Hurwitz H, Fehrenbacher L, Novotny W, et al. Bevacizumab plus irinotecan, fluorouracil, and leucovorin for metastatic colorectal cancer. N Engl J Med 350: 2335-2342, 2004.

15. Hurwitz HI, Fehrenbacher L, Hainsworth JD, et al. Bevacizmab in Combination With Fluorouracil and Leucovorin: An Active Regimen for Metastatic Colorectal Cancer. J Clin Oncol 23: 3502-3508, 2005

16. Giantonio BJ, Catalano PJ, Meropol NJ, et al. Bevacizumab in combination with oxaliplatin, fluorouracil, and leucovorin (FOLFOX4) for previously treated metastatic colorectal cancer: results from the Eastern Cooperative Oncology Group Study E3200. J Clin Oncol 25: 1539-1544, 2007.

17. Broll R, Erdmann H, Duchrow M, et al. Vasculer Endothelia growth factor (VEGF) -a valuable serum tumour marker in patients with colorectal cancer? Eur J Surg Oncol 27: 37-42, 2001.

18. Dirix LY, Vermeulen PB, Pawinski A, et al. Elevated levels of the angiogenic cytokines basic fibroblast growth factor and vascular endothelial growth factor in sera of cancer patients. Br J Cancer 76: 238-243, 1997.

19. Landriscina M, Cassano A, Ratto C, et al. Quantitative analysis of basic fibroblast growth factor and vascular endothelial growth factor in human colorectal cancer. $\mathrm{Br} \mathrm{J}$ Cancer 78: 765-770, 1998. 
International Journal of Hematology and Oncology

20. Cohen $\mathrm{MH}$, Gootenberg J, Keegan P, Pazdur R. FDA drug approval summary: bevacizumab plus FOLFOX4 as secondline treatment of colorectal cancer. Oncologist 12: 356-361, 2007.

21. Burke HB. Outcome prediction and the future of the TNM staging System. J Natl Cancer Inst 96: 1408-1409, 2004.

\section{Correspondence}

Dr. Murat DINÇER

Eskişehir Osman Gazi Üniversitesi Tıp Fak

Tıbbi Onkoloji Anabilim Dalı

Meşelik

ESKIŞEHIR / TURKEY

Tel: (+90.532) 5060249

Fax: (+90.222) 2392979

e-mail: muratdincer@mynet.com 